\title{
Pachydermoperiostosis Mimicking Acromegaly: A Case Report
}

\author{
Akromegaliyi Taklit Eden Pakidermoperiostoz: Olgu Sunumu \\ Mi-Hye KWON, Chung-Il JOUNG \\ Division of Rheumatology, Konyang University Hospital, Daejeon, Korea
}

Pachydermoperiostosis is a rare osteoarthroder-mopathic disorder of which clinical and radiographic presentations may mimic those of acromegaly. In the evaluation of patients with acromegaloid appearances, pachydermoperiostosis should be considered as a differential diagnosis. In this article, we present a 26-year-old man who was admitted with the complaints of painful swelling and stiffness of hands, feet and ankles lasting for about six months.

Key words: Arthralgia; pachydermoperiostosis; primary hypertrophic osteoarthropathy.

Pachydermoperiostosis (PDP), also referred to as primary hypertrophic osteoarthropathy (HOA), is a rare hereditary disorder characterized by clubbing of the digits, thickening of the skin, and periosteal changes in the long bones. When patients with PDP visit a hospital complaining of arthralgia, its clinical and radiological presentation can be diagnostically challenging.

\section{CASE REPORT}

A 26-year-old man visited our clinic presenting with painful swelling and stiffness of the hands, ankles, and feet which had lasted for about six months. Three years previously, with the same presentations, he was diagnosed as having rheumatoid arthritis (RA) at another clinic and had been treated for months. It was determined by that clinic that the disease was in a state of remission. During the
Pakidermoperiostoz, klinik ve radyografik tablosu akromegaliyi taklit edebilen bir osteoartrodermopatik bozukluktur. Akromegaloid görünümlü hastalar değerlendirilirken, pakidermoperiostoz ayırıcı tanı olarak akla getirilmelidir. Bu makalede el, ayak ve ayak bileğinde altı aydır devam eden ağrılı şişlik ve sertlik yakınması ile başvuran 26 yaşında erkek bir olgu sunuldu.

Anahtar sözcükler: Eklem ağrısı; pakidermoperiostoz; primer hipertrofik osteoartropati.

most recent six month period, he had experienced several episodes of lower leg edema which had subsided completely within five days without any treatment, and joint pain in both wrists, elbows, and ankles intermittently. Six years previously, he had undergone an operation for jaw misalignment and lantern jaw. The patient recalled that the overall appearance of his hands, feet, jaw, and face had changed gradually since his late teens.

He had no other pertinent medical or familial history. His blood pressure was normal, and his outer appearance seemed to indicate acromegaly since the contour of the jaw was enlarged and long making his face appear coarse. The patient's facial skin was oily with diffuse acne scars (Figure 1). He did not complain of hair loss, and cutis verticis gyrata was not present. His hands and feet were enlarged with thickened palms and heel pads. Clubbing of the fingers

Received: May 6, 2011 Accepted: January 10, 2012

Correspondence: Chung-II Joung, M.D. Division of Rheumatology, Konyang University Hospital, Daejeon, Korea

Tel: 82-42-600-8817 e-mail: cij1221@kyuh.ac.kr

(2012 Turkish League Against Rheumatism. All rights reserved. 


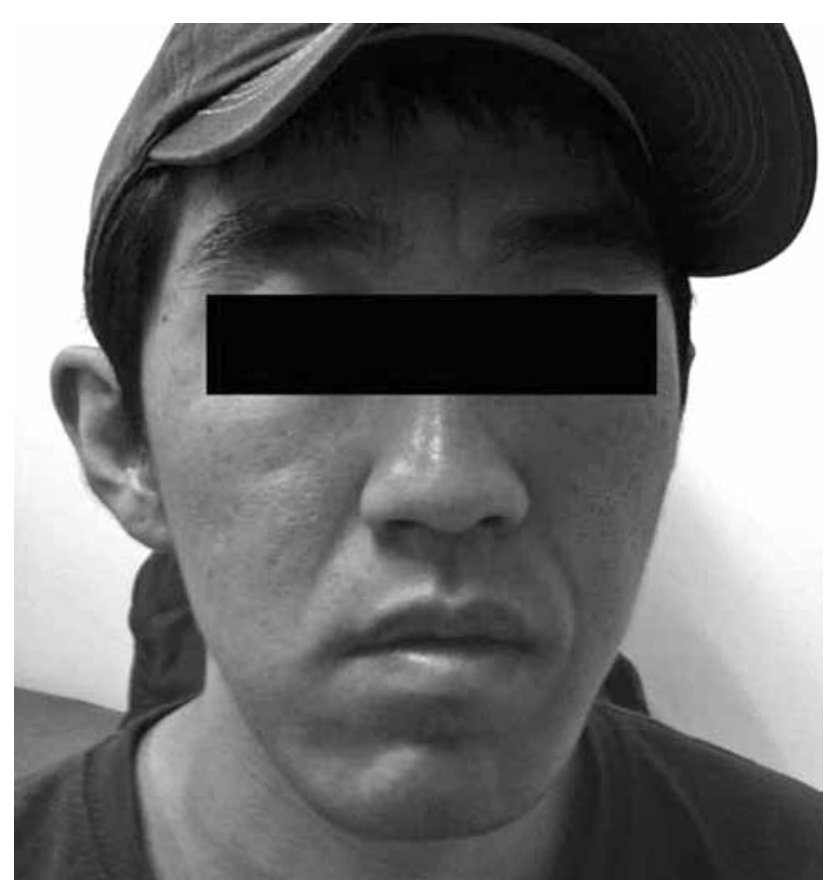

Figure 1. Facial contours were coarse and furrowed with scattered acne scars.

and toes was observed, and the skin of the lateral aspect of the proximal interphalangeal joints of the second to fifth finger was thickened (Figure 2). The patient's palms were sweaty and moist, and both wrists and ankles were swollen and tender without the sense of warmth. Laboratory tests were normal for insulin-like growth factor-1 (IGF-1), thyroid function tests, and pepsinogen-1. His growth hormones were normally suppressed with glucose (75 g) loading. A peripheral blood test revealed a white blood count (WBC) of $8.300 / \mu \mathrm{L}$, a hemoglobin count of $14.8 \mathrm{~g} / \mathrm{dL}$, and a platelet count of $368.000 / \mu \mathrm{L}$. The erythrocyte sedimentation rate (ESR) and C-reactive protein (CRP) level were elevated at $56 \mathrm{~mm} / \mathrm{hr}$ and CRP $1.8 \mathrm{mg} / \mathrm{dL}$, respectively. Negative results were obtained for rheumatoid factor, anti-cyclic citrullinated protein (anti-CCP) antibodies, and HLA-B27. The antinuclear antibody test (ANA) was weakly positive (1:40, nucleolar), but the extractable nuclear antigen (ENA) results were negative for anti-dsDNA, RNP, Ro/La, Smith, Scl70, centromere, and Jo-1 antibodies. $\mathrm{X}$-rays revealed periosteal thickening of the long bones, from the epiphyses to the metaphyses but sparing the diaphyses (Figure 3). The vertebral spines, proximal ends of the humeruses and femurs, and lateral Sellar's view of the skull showed normal bony contours. On bone scintigraphy, a diffusely increased uptake of isotope was observed along the cortical lining of

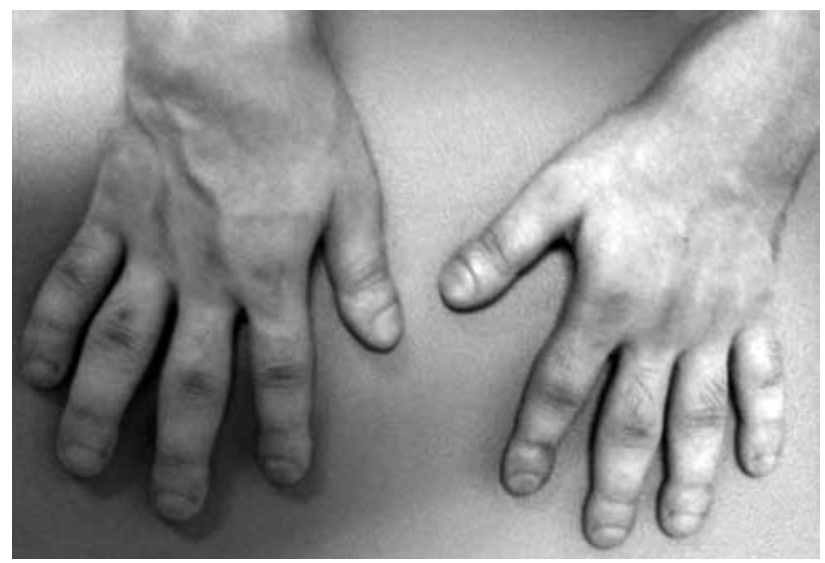

Figure 2. Both hands were thickened and enlarged. Digital clubbing was observed, with skin thickening at the lateral sides of the proximal interphalangeal joints.

the long bones, but there was no abnormal uptake of the isotope suggesting joint pathology. For the evaluation of intermittent epigastric soreness, which had lasted for years, a gastrofibroscopy was done, and the results were nonspecific. The presence of clubbing and radiographic evidence of periostosis of the tubular bones without underlying diseases correctly diagnosed PDP in this patient. He was prescribed non-steroidal anti-inflammatory drugs (NSAIDs) on an as needed basis, and a single dose of intravenous ibandronate
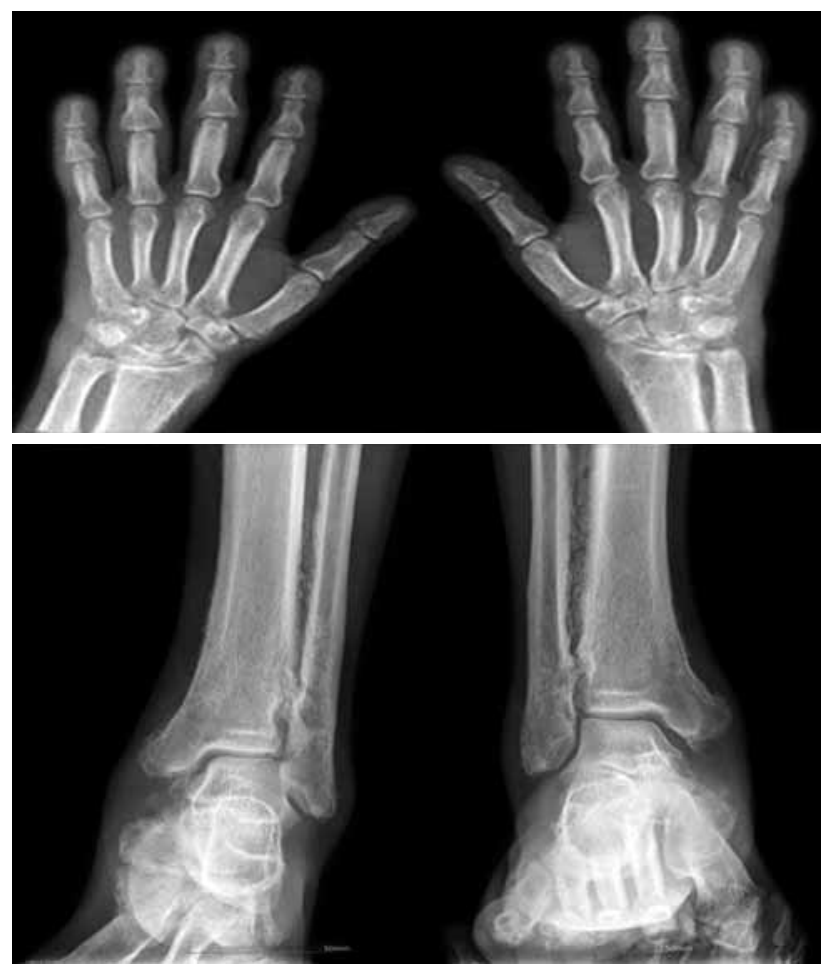

Figure 3. Periosteal reactions were observed along the cortices of the long bones. 
sodium $(3 \mathrm{mg})$. The pain subsided, and the patient continues to be followed up.

\section{DISCUSSION}

Pachydermoperiostosis is a rare hereditary disorder which mainly appears as an autosomal dominant pattern with variable penetration. It was first described in the literature by Friedreich in 1868 when he wrote about two brothers who had the disease. ${ }^{[1]}$ It predominantly affects adolescent males and insidiously progresses to disclose typical presentations such as pachydermia, the thickening and coarsening of facial features, the clubbing of digits, hyperhidrosis, edema in the lower legs, arthritis both with and without joint effusion, and periosteal reaction of the long bones. Pachydermoperiostosis is the primary form of HOA, and secondary HOAs exist with underlying diseases such as malignancy. ${ }^{[2]}$ Diagnosis of HOA is made clinically based on the combination of digital clubbing and periostosis of tubular bones. Pachydermoperiostosis can be classified as complete or incomplete depending on the extent of clinical presentation of symptoms and signs. ${ }^{[3]}$ By definition, the patient presented here seemed to have the complete form of primary PDP since pachydermia, clubbing, and periostosis were observed.

The pathogenesis of PDP is not yet clearly understood; however, recently growing evidence supports that the vascular endothelial growth factor (VEGF) and platelet-derived growth factor (PDGF) could play a central role. ${ }^{[4,5]}$ The VEGF is produced in malignancies and is induced under hypoxic circumstances, such as cardiac or pulmonary diseases. This could explain the cause of vascular hyperplasia, new bone formation, and edema which are classic presentations of HOA. ${ }^{[4]}$ Homozygous mutations in the 15-hydroxyprostaglandin dehydrogenase (HPDG) result in an elevated prostaglandin E2 level, which has been suggested as a pathogenesis of PDP. ${ }^{[6-8]}$ Also, there are other reports related to chromosomal abnormalities and HLA-B12 antigen associations. ${ }^{[9,10]}$ While it is known that one third of PDP patients have a family history, our patient had no family members who had been diagnosed with PDP.

In a few reports, bony erosions, which are considered very rare in PDP, were observed in radiographic images. ${ }^{[11,12]}$ Our patient had neither erosive lesions nor acroosteolysis in the affected bones and joints. Although inflammatory markers, including ESR and
CRP, are generally described as normal in the literature, some other cases, including this one, have had mild to moderate elevated inflammatory markers without evidence of infection. ${ }^{[11,13,14]}$ This might be explained by the fact that this patient had other overlapping inflammatory diseases such as seronegative RA and spondyloarthropathy or by the fact that PDP itself has an inflammatory background, which is contrary to the generally accepted presumption.

Pachydermoperiostosis is very rare, and its clinical and radiological presentations can be confused with those of syphilitic periostitis, psoriatic onychopachydermoperiostitis (POPP), Paget's disease, and, especially, acromegaly. ${ }^{[15]}$

Pachydermoperiostosis cases mimicking acromegaly have been reported so as to bring them to the attention of practitioners. ${ }^{[16]}$ The clubbing of digits, coarse facial features, and enlarged hands and feet from periosteal thickening in patients with PDP can be confused with soft tissue thickening and enlargement of the distal phalanx of the digits along with hypertrophy of the bones and soft tissue in patients with acromegaly. Some patients with HOA may have exuberant skin hypertrophy. Other similarities include hyperhidrosis, oily skin, and joint pain. These features which are present in patients with acromegaly are apparently caused by the effect of excess growth hormones, mainly from pituitary tumors. The articular manifestations of acromegaly, a major cause of morbidity and functional disability, are similar to those of osteoarthritis, particularly in the appendicular and axial skeleton. Inflammation is not prominent, and synovial effusion is uncommon. Otherwise, the weight bearing joints, such as the knees and ankles, are most commonly affected in HOA, and joint swelling is frequently seen in conjunction with the synovial fluid in the rare cases where inflammation occurs. ${ }^{[17]}$ The clues for the differential diagnosis of HOA are digital clubbing and periostosis, which are not features of acromegaly. Pituitary lesions and abnormal hormonal profiles should be excluded for a proper diagnosis.

In case there are accompanying arthritides, known to be present in $20-40 \%$ of PDP patients, RA should be considered as a differential diagnosis, and synovitis with inflammatory synovial fluid can be viewed as a representative characteristic of RA. ${ }^{[12,18]}$

A definitive treatment for PDP has not yet been established, but symptomatic management with NSAIDs, simple analgesics, and intravenous bisphosphonates is currently being used. ${ }^{[19]}$ In addition, 
oral tamoxifen has been reported to be effective for arthralgia that is refractory to NSAIDs. ${ }^{[20,21]}$

\section{Declaration of conflicting interests}

The authors declared no conflicts of interest with respect to the authorship and/or publication of this article.

\section{Funding}

The authors received no financial support for the research and/or authorship of this article.

\section{REFERENCES}

1. Friedrich N. Hyperostose des gesammten skelettes. Virchows Arch Pathol Anat 1868;43:83-7.

2. Benedek TG. Paraneoplastic digital clubbing and hypertrophic osteoarthropathy. Clin Dermatol 1993;11:53-9.

3. Martínez-Lavín M, Matucci-Cerinic M, Jajic I, Pineda C. Hypertrophic osteoarthropathy: consensus on its definition, classification, assessment and diagnostic criteria. J Rheumatol 1993;20:1386-7.

4. Atkinson S, Fox SB. Vascular endothelial growth factor (VEGF)-A and platelet-derived growth factor (PDGF) play a central role in the pathogenesis of digital clubbing. J Pathol 2004;203:721-8.

5. Silveira LH, Martínez-Lavín M, Pineda C, Fonseca MC, Navarro C, Nava A. Vascular endothelial growth factor and hypertrophic osteoarthropathy. Clin Exp Rheumatol 2000;18:57-62.

6. Uppal S, Diggle CP, Carr IM, Fishwick CW, Ahmed M, Ibrahim GH, et al. Mutations in 15-hydroxyprostaglandin dehydrogenase cause primary hypertrophic osteoarthropathy. Nat Genet 2008;40:789-93.

7. Yüksel-Konuk B, Sırmacı A, Ayten GE, Özdemir M, Aslan İ, Yllmaz-Turay Ü, et al. Homozygous mutations in the 15-hydroxyprostaglandin dehydrogenase gene in patients with primary hypertrophic osteoarthropathy. Rheumatol Int 2009;30:39-43.

8. Seifert W, Beninde J, Hoffmann K, Lindner TH, Bassir C, Aksu F, et al. HPGD mutations cause cranioosteoarthropathy but not autosomal dominant digital clubbing. Eur J Hum Genet 2009;17:1570-6.

9. Lee SC, Moon HJ, Cho D, Ryang DW, Kim SJ, Chun IK, et al. Pachydermoperiostosis with cutaneous squamous cell carcinomas. Int J Dermatol 1998;37:693-6.

10. Jajic I, Jajic Z, Ozie-Bebek M. HLA antigens and primary hypertrophic osteoarthropathy. Clin Exp Rheum 1992;10:74.

11. Rastogi R, Suma GN, Prakash R, Rastogi UC, Bhargava S, Rastogi V. Pachydermoperiostosis or primary hypertrophic osteoarthropathy: A rare clinicoradiologic case. Indian J Radiol Imaging 2009;19:123-6.

12. Schumacher HR Jr. Hypertrophic osteoarthropathy: rheumatologic manifestations. Clin Exp Rheumatol 1992;10 Suppl 7:35-40.

13. Auger M, Stavrianeas N. Pachydermoperiostosis. Available from: http://www.orpha.net/data/patho/GB/ uk-pachydermoperiostosis.pdf [Accessed, April 2004]

14. Yao Q, Altman RD, Brahn E. Periostitis and hypertrophic pulmonary osteoarthropathy: report of 2 cases and review of the literature. Semin Arthritis Rheum 2009;38:458-66.

15. Stoker DJ. Pachydermoperiostosis mimicking acromegaly. J R Soc Med 1992;85:306.

16. Mahy IR, Wiggins J. Pachydermoperiostosis mimicking acromegaly. J R Soc Med 1992;85:46-7.

17. Pineda C, Fonseca C, Martinez-Lavin M. The spectrum of soft tissue and skeletal abnormalities of hypertrophic osteoarthropathy. J Rheumatol 1990;17:626-32.

18. Matucci-Cerinic M, Lotti T, Jajic I, Pignone A, Bussani C, Cagnoni M. The clinical spectrum of pachydermoperiostosis (primary hypertrophic osteoarthropathy). Medicine (Baltimore) 1991;70:208-14.

19. Guyot-Drouot MH, Solau-Gervais E, Cortet B, Deprez X, Chastanet $\mathrm{P}$, Cotten A, et al. Rheumatologic manifestations of pachydermoperiostosis and preliminary experience with bisphosphonates. J Rheumatol 2000;27:2418-23.

20. Maeda H, Kumagai K, Konishi F, Katayama Y, Hiyama $\mathrm{K}$, Ishioka S, et al. Successful treatment of arthralgia with tamoxifen citrate in a patient with pachydermoperiostosis. Rheumatology (Oxford) 2000;39:1158-9.

21. Bianchi L, Lubrano C, Carrozzo AM, Iraci S, Tomassoli M, Spera G, et al. Pachydermoperiostosis: study of epidermal growth factor and steroid receptors. $\mathrm{Br} \mathrm{J}$ Dermatol 1995;132:128-33. 